\title{
OBSERVASI EFEK EKSTRAK ETANOL DAUN BAMBU JAWA (Gigantochloa atter (Hassk.) Kurz) DENGAN PARAMETER FISIK DAN FISIOLOGI HEWAN UJI TIKUS (Rattus sp.)YANG DIINDUKSI BORAKS
}

\author{
Hardadi Airlangga ${ }^{1}$, Endand Sawitri ${ }^{1}$,Novi Arfarita ${ }^{2,1}$ \\ ${ }^{1}$ Fakultas Kedokteran, Universitas Islam Malang \\ ${ }^{2}$ Fakultas Pertanian, Universitas Islam Malang \\ email:arfarita@yahoo.com
}

\begin{abstract}
ABSTRAK
Bamboo Jawa leaves (Gigantochloa atter) is known to contain antioxidant compound sandhas been used as abeverage from generation to generation invarious Asiancountries. While in Indonesia, currently borax widely abusedas a food preservative and food additives. Borax produce exogenous free radicals that can lead to organ damage due to oxidative stress.This current study was to observe the effect of ethanolic extract of G. atter leaf using physiology and physical parameter onthe levels of SOD, MDA and the hepatosite necrosis totalof rats induced by borax. Borax will generate free radicals which cause cell damage through lipid peroxidation there by increasing the levels of MDA and lower SOD antioxidant. Borax metabolism occurs mostlyin theliver, therefore, one of the organs damaged by borax is liver The method of this research was experimental control group posttest only using wistar rats which divided into five groups. The negative control group was induced by aquades. The positive control group was induced by borax $1 \mathrm{gr} / \mathrm{kg} B W$ and treatment group was induced by borax. Ethanolic extract of $G$. atter leaf was given with doses of $10 \mathrm{mg} / \mathrm{ml}, 20 \mathrm{mg} / \mathrm{ml}$ and $40 \mathrm{mg} / \mathrm{ml}$ for 21 days. After 21 days of treatment, hepatocite necrosis was then observed and counted using microscope trinocular 1000x. SOD examination was conducted by the NBT test while the MDA using TBA test. Data analysis was using one way ANOVA test. G. atter ethanolic extract dosageof $10 \mathrm{mg} / \mathrm{ml}, 20 \mathrm{mg} / \mathrm{ml}$ and $40 \mathrm{mg} / \mathrm{mlcould}$ decrease the number of liver cells necrosis. They were 23\%, 39\% and $63 \%$ respectivelly when compared to positive control. Extract ethanolik of G.Atter leaf also could improve SOD and decrease MDA rats serum which induced by borax. The effective dose is $20 \mathrm{mg} / \mathrm{ml}$.
\end{abstract}

Keywords: Bamboo Jawa, ethanolic extract, Physiology, Physic

\section{PENDAHULUAN}

Boraks $\left(\mathrm{Na}_{2} \mathrm{~B}_{4} \mathrm{O}_{7} 10 \mathrm{H}_{2} \mathrm{O}\right)$ diproduksi peruntukannya adalah sebagai bahan dalam industri non pangan seperti bahan solder, bahan pembersih, pengawet kayu, antiseptik dan pengontrol kecoa (Hunt, 2007; Nantasen et al., 2006). Akan tetapi borakstelahdisalahgunakan masyarakat Indonesia sebagai bahan pengawet dan tambahan makanan (Daniyati, 2009). Sebetulnya pemerintah telah melarang penggunaan boraks melalui Permenkes No. 33 Tahun 2012 karena berdampak buruk pada kesehatan dan sifatnya yang terakumulasi dalam tubuh. Akan tetapi, berdasarkan survei keamanan pangan pada 1.504 industri rumah tangga pangan di 18 provinsi yang dilakukan Badan POM RI (2009) menunjukkan bahwa terdapat penyalahgunaan bahan berbahaya seperti formalin $(4,89 \%)$, boraks $(8,80 \%)$, rhodamin B, dan methanyl yellow $(4,89 \%)$ (Anonim, 2013).

Boraks dapat membentuk radikal bebas eksogen yang masuk kedalam tubuh melalui gastrointestinal dan mengiritasi mukosa gaster serta ileum, kemudian masuk kedalam aliran darah, dimetabolisme dihati dan diekskresikan oleh ginjal melalui urin. Radikal bebas yang dibentuk oleh boraks merupakan jenis radikal bebas hidroksil ('OH). Radikal bebas yang tidak diimbangi dengan antioksidan dapat menyebabkan stress oksidatif yang dapat merusakan pada tingkat seluler, jaringan dan organ (Priyanto, 2011).

Radikal hidroksil dapat menimbulkan reaksi rantai yang dikenal dengan nama peroksidasi lipid (Arief, 2005). Hasil akhir proses oksidasi dalam membran sel adalah terbentuknya Malondialdehyde (MDA) dan dalam kadar yang tinggi akan menyebabkan 
toksik. Efek radikal bebas tersebut bisa diredam oleh sistem pertahanan antioksidan yang memadai. Superoxide dismutase (SOD) merupakan salah satu antioksidan endogen yang berperan dalam mengkatalisis radikal bebas. Status oksidan yang tinggi biasanya diikuti oleh penurunan kadar SOD.Metabolisme boraks sebagian besar terjadi di hepar (Marjuki, 2009). Karena itu salah satu organ yang mengalami kerusakan akibat boraks adalah hepar (Mohora et al., 2005) Pemberian boraks pada tikus selama dua puluh satu hari dengan dosis satu gram dapat meningkatkan jumlah nekrosis sel hepatosit, meningkatkan kadar MDA hepardan meningkatkan kadar SGOT (Serum Glutamic Oxaloacetic Transaminase) serta kadar SGPT(Serum Glutamic Piruvic Transaminase) hepar (Sholihah, 2010).Meskipun sel hepar mempunyai kemampuan regenerasi sel yang sangat baik dan stabil, namun apabila terjadi kerusakan sel yang berat, arsitektur sel hepar tidak dapat dibentuk kembali dengan sempurna (Underwood, 1999).

Daun G. atter sangat mudah dijumpai disekitar kita. Di Cina, daun bambu telah digunakan dalam pengobatan tradisional untuk mengobati demam dan untuk detoksifikasi. Selain itu daun bambu juga digunakan untuk acara tradisi upacara minum teh sejak lama di Jepang. Tradisi minum seduhan dan pengobatan tradisonal daun bambu telah terbukti baik dan aman untuk kesehatan. Ditunjang dengan penelitian Zhao-lin et al., (2012) menyatakan bahwa daun bambu mengandung senyawa antioksidan (Goyal and Birendra, 2014; ZhaoLin et al., 2012). Namun penelitian tentang daun $G$. atter dan pemanfaatannya sebagai obat alternatif yang merupakan tanaman indigenous Indonesia belum dilaporkan. Berdasarkan fakta tersebut, peneliti ingin mempelajari pengaruh ekstrak etanolik daun $G$. atter terhadap kadar SOD dan kadar MDA pada serum tikus, didukung dengan dengan data observasi secara fisik yaitu efek terhadap perubahan jumlah nekrosis hepatosit tikus wistar yang diinduksi boraks.

\section{BAHAN DAN CARA KERJA}

\section{Metode Penelitian}

Penelitian ini menggunakan metode eksperimental laboratorik secara in vivo menggunakan desain penelitian control grup post test only. Hewan coba yang digunakan dalam penelitian ini adalah tikus strain wistar jantan berusia 2-3 bulan dengan berat badan 180-250 gram. Seluruh hewan coba pada penelitian ini telah mendapatkan persetujuan Komite Etik Fakultas Kedokteran Universitas Brawijaya yang dikeluarkan pada tanggal 9 Mei 2014 dengan nomor 320/EC/KEPKS1/05/2014.

\section{Pembuatan Ekstrak Daun G. atter}

Ekstrak berasal dari daun $G$. atter yang diperoleh dari UPT Materia Medica kota Batu kemudian dibuat simplisia dan dijadikan serbuk. Daun bambu jawa sebanyak $200 \mathrm{~g}$ dimaserasi dengan 2 liter etanol 96\%. Larutan dishaker selama 12 jam kemudian dievaporasi. Ekstraks kental kemudian dijadikan tiga dosis dengan pengenceran $10 \mathrm{mg} / \mathrm{ml}, 20 \mathrm{mg} / \mathrm{ml}$ dan 40 $\mathrm{mg} / \mathrm{ml}$.

\section{Induksi Boraks}

Induksi boraks adalah dengan melarutkan serbuk boraks dalam aquades dengan dosis pemberian tiap tikus $1 \mathrm{~g} / \mathrm{KgBB} /$ hari selama 21 hari per sonde. Pemberian pada semua kelompok kecuali kontrol negatif (Rosalina, 2011).

\section{Perlakuan Hewan Coba}

Hewan coba diadaptasi selama 7 hari sebelum diberi perlakuan. Hewan coba dibagi menjadi 5 kelompok yaitu kelompok kontrol negatif (KN) hanya diberi aquades, kelompok kontrol positif diinduksi boraks $1 \mathrm{gr} / \mathrm{Kg}$ BB (KP), dan kelompok pemberian boraks serta ekstrak etanolik daun bambu Jawa dengan dosis masing-masing $10 \mathrm{mg} / \mathrm{ml}$ (P1), 20mg/ml (P2), dan $40 \mathrm{mg} / \mathrm{ml}$ (P3) yang diberikan personde lambung pemberian ekstrak diberikan 1 jam setelah induksi borak. Penelitian dilakukan selama 21 hari.

\section{Pemeriksaan Kadar SOD}

Pemeriksaan kadar SOD yang menggunakan uji hambat NBT (nitro blue tetrazolium) yang kemudian diamati perubahan warnanya menggunakan spektrofotometer pada panjang gelombang $580 \mathrm{~nm}$ (Wong et. al., 1989).

\section{Pemeriksaan Kadar MDA}

Pemeriksaan kadar MDA menggunakan uji asam thiobarbiturat (TBA test) yang kemudian diamati perubahan warnanya menggunakan spektrofotometer dengan panjang gelombang $532 \mathrm{~nm}$ (Burleson et al., 1995)

\section{Pembuatan Preparat Histologi}

Pembuatan preparat histologi di laboratorium Patologi Anatomi Rumah Sakit Aisiyah Malang. Organ Hepar dipotong secara longitudinal hingga berukuran (10-15) $\mathrm{mm} \mathrm{x}$ $(10-15) \mathrm{mm}$ x $5 \mathrm{~mm}$. Kemudian dilakukan 
proses dehidrasi, cleaning, dan embeding, selanjutnya dilakukan proses pemotongan dengan menggunakan mikrotom setebal 3-5 $\mu \mathrm{m}$ sebelum dilakukan pewarnaan Hemaktosilin Eosin (HE) (Rosalina, 2011).

\section{Pemeriksaan Struktur Hepar}

Sediaan prepatrat histologi hepar diperiksa dengan mikroskop triokular untuk melihat keadaan sel-sel hepar serta adanya tanda-tanda nekrosis yang dilihat dengan pembesaran 40 kali untuk melihat struktur histologi hepar secara keseluruhan, pembesaran 1000 kali dengan 5 kali lapang pandang tiap zona untuk menghitung jumlah nekrosis sel hepar dengan menggunakan penghitungan manual dan dilakukan dua kali penghitungan untuk tiap slide preparat.

\section{Teknik Analisa Data}

Data yang diperoleh diuji secara statistik menggunakan analisis One Way ANOVA dengan syarat sudah homogen dan terdistribusi normal dilanjutkan dengan LSD. Hasil dikatakan bermakna bila $\mathrm{p}<0.05$.

\section{HASIL DAN PEMBAHASAN}

\section{Uji G. atter Terhadap Kadar MDA Serum} Tikus Wistar yang Diinduksi Boraks

Kadar MDA serum tikus yang diinduksi boraks dan disuplementasi ekstrak etanol daun G. atter dapat dilihat pada Tabel 1 dan Gambar 1.

Tabel 1.Rerata Kadar MDASerum Tikus Pasca Induksi Boraks dan Ekstrak Etanol Daun Bambu Jawa (G. atter)

\begin{tabular}{|c|c|c|}
\hline Perlakuan & $\mathbf{N}$ & $\begin{array}{c}\text { Rerata Kadar } \\
\text { MDA } \\
\end{array}$ \\
\hline $\begin{array}{l}\mathbf{K N} \\
\text { (aquades } 2 \mathrm{ml} \text { ) }\end{array}$ & 3 & $41,5 \pm 2,5 \mu \mathrm{g} / \mathrm{ml}$ \\
\hline $\begin{array}{l}\text { KP } \\
\text { (boraks } 1 \\
\text { gr/kgBB) }\end{array}$ & 3 & $56,5 \pm 12,5 \mu \mathrm{g} / \mathrm{ml}^{\mathrm{a}}$ \\
\hline $\begin{array}{l}\text { P1 } \\
\text { Boraks + } \\
\text { Ekstrak etanol } \\
\text { daun bambu } \\
\text { jawa } 10 \mathrm{mg} / \mathrm{ml}\end{array}$ & 3 & $44 \pm 0,0 \mu \mathrm{g} / \mathrm{ml}^{\mathrm{b}}$ \\
\hline $\begin{array}{l}\text { P2 } \\
\text { Boraks + } \\
\text { Ekstrak etanol } \\
\text { daun bambu } \\
\text { jawa } 20 \mathrm{mg} / \mathrm{ml}\end{array}$ & 3 & $44 \pm 0,0 \mu \mathrm{g} / \mathrm{ml}^{\mathrm{b}}$ \\
\hline $\begin{array}{l}\text { P3 } \\
\text { Boraks + } \\
\text { Ekstrak etanol } \\
\text { daun bambu } \\
\text { jawa } 40 \mathrm{mg} / \mathrm{ml}\end{array}$ & 3 & $51,5 \pm 2,5 \mu \mathrm{g} / \mathrm{ml}$ \\
\hline
\end{tabular}

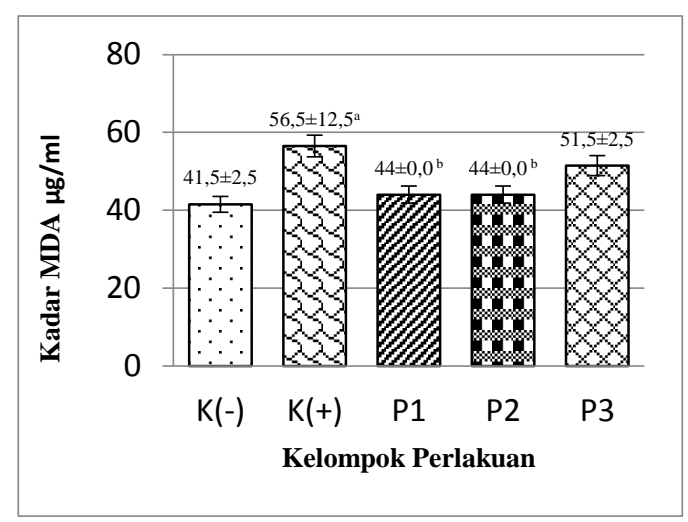

Gambar 1. Rerata Kadar MDA Serum Tikus Pasca Induksi Boraks dan Ekstrak Etanol Daun G. atter.

Berdasarkan Tabel 1 dan Gambar 1 menunjukkan bahwa pemberian ekstrak etanol daun G. atter dosis $10 \mathrm{mg} / \mathrm{ml}$ dan $20 \mathrm{mg} / \mathrm{ml}$ dapat menurunkan kadar MDA secara signifikan dengan nilai yang sama sekitar $22 \%$ dibandingkan dengan kontrol positif $(p<0,05)$, tetapi pada dosis $40 \mathrm{mg} / \mathrm{ml}$ tidak dapat menurunkan kadar MDA secara signifikan dibandingkan kontrol positif $(\mathrm{p}>0,05)$. Pemberian ekstrak daun bambu jawa dosis 10 $\mathrm{mg} / \mathrm{ml}, 20 \mathrm{mg} / \mathrm{ml}$ dan $40 \mathrm{mg} / \mathrm{ml}$ tidak berbeda signifikan menurunkan kadar MDA ( $p>0,05)$. Suplementasi ektrak daun bambu jawa dosis 10 $\mathrm{mg} / \mathrm{ml}$ dan $20 \mathrm{mg} / \mathrm{ml}$ dapat menurunkan kadar MDA hingga tidak berbeda signifikan dibandingkan kelompok kontrol negatif (p>0,05). Pemberian ekstrak etanol daun $G$. atter dalam dosis $10 \mathrm{mg} / \mathrm{ml}$ dan $20 \mathrm{mg} / \mathrm{ml}$ dapat menurunkan kadar MDA secara signifikan $(\mathrm{p}<0.05)$ dibandingkan kelompok kontrol positif. Hal ini diduga karena ekstrak etanol daun bambu jawa memiliki senyawa yang bersifat sebagai antioksidan seperti flavonoid yang berfungsi sebagai antioksidan untuk menangkal radikal bebas atau oksidan sehingga kadar MDA mampu diturunkan.

Kelompok perlakuan 3 dengan dosis $40 \mathrm{mg} / \mathrm{ml}$ tidak berbeda antara kelompok kontrol negatif, positif, perlakuan 1 dan 2 namun mengalami peningkatan kadar MDA serum. Hal ini karena kadar senyawa antioksidan tertentu pada dosis yang berlebihan dapat berubah menjadi prooksidan dan pada kelompok fenolik aktivitas antioksidan sering lenyap, sehingga dapat memperparah terjadinya kerusakan oksidatif akibat radikal bebas (Silvia, 2009). Hal ini dibuktikan dengan peningkatan MDA serum yang juga berkaitan dengan 
rendahnya aktivitas antioksidan yang terkandung dalam daun G. atter.

Efek Ekstrak Etanol Daun G. atter Terhadap Aktivitas SOD Serum Pada Tikus yang Diinduksi Boraks

Aktivitas SOD serum tikus yang induksi boraks dan disuplementasi ekstrak etanol daun $G$. atter dapat dilihat pada Tabel 2 dan Gambar 2.

Tabel 2. Rerata Aktivitas SOD Serum Tikus Pasca Induksi Boraks dan Pemberian Ekstrak Etanol Daun G. atter

\begin{tabular}{|c|c|c|}
\hline Perlakuan & $\mathbf{N}$ & $\begin{array}{c}\text { Rerata } \\
\text { Kadar SOD }\end{array}$ \\
\hline $\begin{array}{l}\text { KN } \\
\text { (aquades } 2 \mathrm{ml} \text { ) }\end{array}$ & 5 & $\begin{array}{c}6,7 \pm 0,58 \\
\mu \mathrm{g} / \mathrm{ml}\end{array}$ \\
\hline $\begin{array}{l}\text { KP } \\
\text { (boraks } 1 \text { gr/kgBB) }\end{array}$ & 5 & $\begin{array}{c}6,2 \pm 0,56 \\
\mu \mathrm{g} / \mathrm{ml}^{\mathrm{a}}\end{array}$ \\
\hline $\begin{array}{l}\text { P1 } \\
\text { Boraks + Ekstrak } \\
\text { etanol daun bambu } \\
\text { jawa } 10 \mathrm{mg} / \mathrm{ml}\end{array}$ & 5 & $\begin{array}{c}6,6 \pm 0,46 \\
\mu \mathrm{g} / \mathrm{ml}\end{array}$ \\
\hline $\begin{array}{l}\text { P2 } \\
\text { Boraks + Ekstrak } \\
\text { etanol daun bambu } \\
\text { jawa } 20 \mathrm{mg} / \mathrm{ml}\end{array}$ & 5 & $\begin{array}{l}6,8 \pm 0,3 \\
\mu \mathrm{g} / \mathrm{ml}^{\mathrm{b}}\end{array}$ \\
\hline $\begin{array}{l}\text { P3 } \\
\text { Boraks + Ekstrak } \\
\text { etanol daun bambu } \\
\text { jawa } 40 \mathrm{mg} / \mathrm{ml}\end{array}$ & 5 & $\begin{array}{l}7,6 \pm 0,33 \\
\mu \mathrm{g} / \mathrm{ml}{ }^{\mathrm{bc}}\end{array}$ \\
\hline
\end{tabular}

Berdasarkan Tabel 2 dan Gambar 2 pemberian ekstrak etanol daun G. atter dosis $20 \mathrm{mg} / \mathrm{ml}$ dan $40 \mathrm{mg} / \mathrm{ml}$ dapat meningkatkan aktivitas SOD secara signifikan berturut - turut sekitar 9\% dan 18\%dibandingkan dengan kelompok kontrol positif $(p<0,05)$ tapi pada pemberian ekstrak daun bambu jawa dosis $10 \mathrm{mg} / \mathrm{ml}$ tidak dapat meningkatkan aktivitas SOD secara signifikan dibandingkan kelompok kontrol positif ( $>0,05)$. Pemberian ekstrak daun bambu jawa dosis $20 \mathrm{mg} / \mathrm{ml} \mathrm{dan} 40 \mathrm{mg} / \mathrm{ml}$ tidak berbeda signifikan meningkatkan aktivitas SOD ( $>00,05)$, sedangkan pemberian ekstrak daun bambu jawa dosis $40 \mathrm{mg} / \mathrm{ml}$ berbeda signifikan meningkatkan aktivitas SOD dibandingkan dengan $10 \mathrm{mg} / \mathrm{ml}(\mathrm{p}<0,05)$.Suplementasi ektrak daun bambu jawa dosis $20 \mathrm{mg} / \mathrm{ml}$ dan $40 \mathrm{mg} / \mathrm{ml}$ dapat meningkatkan aktivitas SOD hingga tidak berbeda signifikan dibandingkan kelompok kontrol negatif $(p>0,05)$.

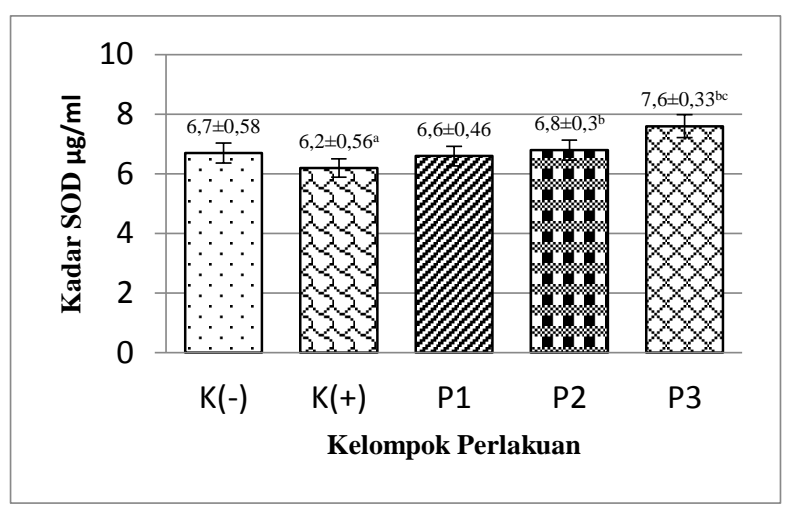

Gambar 2. Rerata Aktivitas SOD Serum Tikus Pasca Induksi Boraks dan EkstrakEtanol Daun G. atter.

Pemberian ekstrak etanol daun $G$. atter dosis $20 \mathrm{mg} / \mathrm{ml}$ dan $40 \mathrm{mg} / \mathrm{ml}$ dapat meningkatkan aktivitas SOD secara signifikan $(\mathrm{p}>0.05)$ dibandingkan kontrol positif. Hal ini diduga karena ekstrak etanol daun bambu jawa memiliki senyawa yang bersifat sebagai antioksidan seperti flavonoid. SOD mampu mengubah oksidan yang dihasilkan boraks menjadi hidrogen peroksidase atau oksidan yang lebih stabil dan dengan bantuan catalase serta glutathione peroksidase akan mampu mengubah oksidan tersebut menjadi air dan oksigen. Ekstrak etanolik daun $G$. atter dengan dosis $10 \mathrm{mg} / \mathrm{ml}, 20 \mathrm{mg} / \mathrm{ml}$ dan $40 \mathrm{mg} / \mathrm{ml}$ dapat menghasilkan flavonoid yang mampu meningkatkan kerja dari enzim SOD sebagai antioksidan. Pada penelitian Arvind et al., (2013) daun bambu memiliki efek antioksidan yang tinggi dan kuat untuk melawan radikal bebas bahkan dari dosis terendah hingga dosis tinggi.Pada penelitian ini dapatkan hasil semakin tinggi dosis ekstrak etanolik daun $G$. atter maka peningkatan kadar SOD serum semakin berarti, dengan kata lain adanya hubungan berbanding lurus antara peningkatan dosis dengan peningkatan kadar SOD serum.

\section{Efek Ekstrak Etanolik Daun G. atter terhadap Jumlah Nekrosis Hepatosit Tikus yang Diinduksi Boraks}

Jumlah nekrosis hepatosit tikus pada kelompok yang disuplementasi ekstraks etanolik daun bambu jawa selama 21 hari ditunjukkan pada Gambar 3. Gambar 3 menunjukkan bahwa pemberian ekstraks etanolik daun $G$. atter $\mathrm{mg} / \mathrm{mL}$ dapat menurunkan jumlah nekrosis hepatosit pada tikus secara signifikan dibandingkan dengan kontrol positif. Pada 
perlakuan P1 (pemberian ekstraks etanolik daun bambu jawa $10 \mathrm{mg} / \mathrm{ml}$ ) mampu menurunkan jumlah nekrosis hepatosit sebesar 23\%, sedangkan pada pada perlakuan P2 (pemberian ekstraks etanolik daun bambu jawa $20 \mathrm{mg} / \mathrm{ml}$ ) mampu menurunkan jumlah nekrosis hepatosit sebesar 39\%. Perlakuan P3 (pemberian ekstraks etanolik daun $G$. atter $40 \quad \mathrm{mg} / \mathrm{mL}$ ) menghasilkan tikus dengan nekrosis yang lebih baik yaitu sebesar $63 \%$. Hasil nekrosis perzona hepar menunjukkan zona III memiliki jumlah nekrosishepatositterbanyak hampir pada semua kelompok perlakuan setelah pajananboraks dan pada semua zona mengalami penurunan jumlah nekrosis hepatosit setelah diberi ekstrak etanolik daun G. atter.

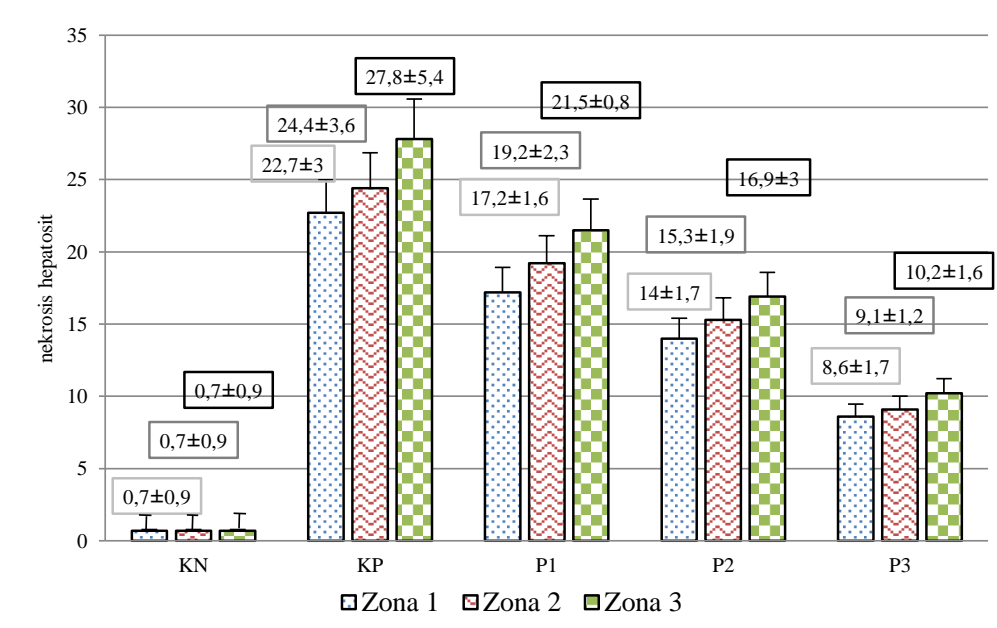

Gambar 3. Rerata Zona Nekrosis Hepatosit Tikus yang Diinduksi Boraks dan Ekstraks Etanolik Daun Bambu Jawa.

\section{KESIMPULAN}

Berdasarkan dari hasil analisa data dan pembahasan disimpulkan bahwa induksi boraks $1 \mathrm{~g} / \mathrm{kg}$ BB mampu menurunkan kadar SOD dan meningkatkan kadar MDA serum.Pemberian ekstrak etanolik daun G. atter dosis $20 \mathrm{mg} / \mathrm{ml}$ mampu meningkatkan kadar SOD dan menurunkan kadar MDA serum pada tikus yang diinduksi boraks secara signifikan terhadap kontrol positif.Ekstrak etanolik daun $G$. atter dengan dosis $10 \mathrm{mg} / \mathrm{mL}, 20 \mathrm{mg} / \mathrm{mL}$ dan 40 $\mathrm{mg} / \mathrm{mL}$ dapat menghambat peningkatan jumlah nekrosis sel hepar tikus dengan pajanan boraks $1 \mathrm{~g} / \mathrm{KgBB}$.

\section{DAFTAR PUSTAKA}

Anonim. 2013. Peningkatan Pemahaman Standar Keamanan Pangandalam Mendukung Daya Saing Produk Pangan. 21 Mei 2014.

Arief S. Radikal Bebas .2005 [update $2011 \mathrm{Mei}$ 10; cited 2012 Des 12]. Available from: http://www.pediatrik.com/buletin/0622 4113752-x0zu61.doc.

Arvind G, Middha SK., and Sen A. 2013. Bambusa vulgaris Schrad. ex J. C. Wendl. var. Vittata Riviere \& C. Riviere leaves attenuate oxidative stress- An in vitro biochemical assay: Journal of Natural Products and Resources. Molecular Cytogenetics Laboratory. Department of Biotechnology, Bangalore-560012, Kamataka, India.

Burleson GR., Dean JH., and MunsonAE. 1995. Methods in immunotoxicology.

New York: Wiley-Liss, Inc.

Daniaty L. 2009. Pengetahuan, Sikap dan Tindakan Siswa Tentang Makanan dan Minuman Jajanan yang Mengandung Bahan Tambahan Makanan (BTM) Tertentu di SMP Negeri 3 dan SMA Negeri 1 Binjai. Fakultas Kesehatan Masyarakat Universitas Sumatera Utara Medan.

Goyal A., and Birendra K. 2014. Antioksidan and Nutraceutical Potential of Bamboo: 
an overview. Bamboo Technology, Department of Biotechnology, Bodoland University, Kokrajhar783370, B.T.A.D, Assam, India

Hunt, CD. 2007. Dietary Boron:Evidence for Essentiality and Homeostatic Control in Humans and Animals. Advances in Plant and Animal Boron Nutrition; Xu, F. Ed.; U.S. Department of Agriculture, Agricultural Research Center: Grand Forks, ND; pp 251-267.

Lu BY., Wu XY., and Zang Y. 2005. Toxicology and Safety of Antioxidant of Bamboo Leaves. Part: Acute and Subkronik Toxicity Studies on Antioxidant of Bamboo Leaves,Food Chem. Toxicol, 43, 783-792.

Marjuki A. 2009. Uji Aktivitas Penangkap Radikal Isolat dari Fraksi Ekstrak Etanol Daun Dewandaru (Eugenia uniflora l.) dengan Metode DPPH. Fakultas Farmasi Universitas Surakarta.

Mohora M., Boghianu L., Muscurel C., Duta,C., and Dumitrach C. 2005. Effect of Boric Acid on Redox Status In The Rat Liver,Rom. Journal Biophys, 12, 77-82.

Nantasen I., Ratana B., Viboon R., Sivinee B. and Veeravorn A. 2006. Effect of Borax on Glutathione Levels in Human Red Blood Cells in Vitro. Department of Biochemistry. Department of Surgery. Faculty of Medicine. Chiang Mai University.

Priyanto. 2009. Toksikologi, Mekanisme,

Terapi Antidotum, dan Penilaian Resiko. Leskofi (Lembaga Studi dan Konsultasi Farmakologi, Depok-Jawa Barat.

Rosalina H. 2011. Perbandingan Pengaruh Perasan Kunyit (Curcuma domestica), Temulawak (Curcuma xanthoriza $R O X B$ ) dan Kombinasinya terhadap Kadar MDA (Malondialdehyde) Ileum Tikus Wistar yang Diinduksi Boraks. Fakultas Kedokteran Universitas Islam Malang.

Silvia F. 2009. Aktivitas Spesifik Katalase Jaringan Jantung Tikus yang Diinduksi Hipoksia Hipobarik Akut Berulang. Fakultas Kedokteran Universitas Indonesia. Jakarta.

Sholihah N. 2010. Pengaruh Perasan Kunyit (Curcuma Domestica) dan Perasan Temulawak (Curcuma Xanthorrhiza
$R O X B$ terhadap Gambaran

Histopatologi Hepar Tikus yang Diinduksi Boraks Subakut. Skripsi. Fakultas Kedokteran Universitas Islam Malang.

Underwood JCE. 1999. Patologi Umum dan Sistemik.EGC. Jakarta.

Wong, G.H.W., Elwell, J.H., Oberley, L.W.1989. Manganous superoxide dismutase is essential for cellular resistance to cytotoxicity of tumor necrosis factor. The Cell Journals, 58, 923-931.

Zhao-Lhin L., Xi L.,Zhi-Hui M., Hong-Xuan G., Wan, Jun-Ang-Hong., Lei, MeiLing., Pan, Yue., Zhang, Bo-Lin. 2012. Antioxidant activity of bamboo-leaf extracts from the species Dendrocalamopsis oldhami. Beijing Forestry University. Beijing. China. ISSN 1992-2248. 